\title{
The Failure of the Sport7 TV-channel: Controversies in a Business Network*
}

\section{Harry Sminia}

\author{
Vrije Universiteit
}

ABstRact During 1996, TV viewers in the Netherlands witnessed the rise and fall of Sport7: a dedicated sports TV channel. Apparently, Sport7 did not succeed to become part of the business network of television and sports. This paper describes and explains why the venture failed. It builds on earlier insights from research on the outcomes of joint ventures and the business networks perspective. These insights are combined and utilized within the framework of the theory of social becoming (Sztompka, 1991). As such, for a new venture like Sport7, the outcome depends on the settlement of a number of controversies that arise with the establishment of a new actor in an existing business network. In the case of Sport7, the settlement of these controversies appeared to go against this new venture, ultimately leading to the demise of this new TV channel.

\section{INTRODUGTION}

In a press conference on 10 February 1996, the chairman of the Royal Dutch Football Association (KNVB) made a statement. 'We are going to do something new. Something that has never been done before in the Netherlands, and maybe in the world'. ${ }^{[1]}$ He continued to explain the KNVB, with a few other investors, was about to start a dedicated sports TV channel, which later adopted the Sport7 name. In another press conference, this time on 7 December 1996, the chairman of the supervisory board of the Sport7 company, acting on behalf of the shareholders, announced Sport7 was going into suspension of payment. Broadcasting would stop the next day. Apparently, this new venture had failed.

The Sport7 case offers an outstanding opportunity to learn and expand knowledge on what happens during processes like these to work towards a better under-

Address for reprints: Harry Sminia, Department of Public Administration and Organization Science, Faculty of Social Sciences, Vrije Universiteit, De Boelelaan 1081c, 1081 HV Amsterdam, The Netherlands(h.sminia@mdw.vu.nl). 
standing of why a new venture fails. The literature suggests several lines of reasoning that can be pursued. The Sport7 venture grew out of a business consortium of seven investors, and had to grow into a company in its own right. Research on the outcome of these kinds of ventures has been limited to joint ventures between just two partners that mostly concerned cooperation in the realm of research and development (Ariño and de la Torre, 1998; Ariño and Doz, 2000; Doz, 1996; Doz et al., 2000; Ring and Van de Ven, 1994; Zajac and Olsen, 1993). This research put forward similar models of the cooperation process. A distinction is made between phases of initializing and negotiation, of actual interaction, and of adaptation to changing circumstances, in some form or another. Overall, for a joint venture to succeed, the emphasis is put on the importance of the learning process that has to take place within and around the joint venture. To Doz (1996), this learning has a cognitive dimension (what people understand of how the venture should be handled) and a behavioural dimension (what people can do to better manage the venture). When learning does take place, the cooperation process turns into a kind of positive feedback loop, amplifying initial achievement into greater success.

Following this line of reasoning, any explanation why a new venture fails or succeeds has to start with reasons why learning had not taken place sufficiently. The initial conditions are thought to have a heavy bearing on the outcome of a cooperative venture (Ariño and de la Torre, 1998; Ariño and Doz, 2000; Doz, 1996; Doz et al., 2000). The question is whether the circumstances at the moment of start up allow the learning process to take place. These initial conditions amount to the definition of the task to be performed, a set of routines borrowed from each of the partners, and the interface design between the partners and expectations about the performance of the venture. Each of these conditions potentially either facilitates or hampers the learning that has to take place. Additionally, a model of relational quality has been proposed to help understand the success and failure of joint ventures (Ariño et al., 2001). In this model, relational quality is seen as both an input and an outcome of the alliance process. Furthermore, relational quality is seen to depend, not only on the initial conditions, but also on the negotiation process, partner interactions, and external events. However, much of this work, including this model, focuses on the relationship between the joint venture partners. For a new business venture to succeed, there are more relationships that need to be changed or newly established.

Another line of reasoning stems from the business networks perspective. The network structure, consisting of actors, activities, and resources, constitutes the context against which a business actor has to operate (Anderson et al., 1994). Consequently, for a new venture to succeed, it has to become part of the appropriate business network. For one, this means that this new actor has to enter and maintain a sufficient number of meaningful relationships with other relevant actors. These relationships predominantly are buyer/supplier relationships. And, of 
course, where there are buyer/supplier relationships, there usually are competitive relationships as well.

Within the realm of industrial marketing, it has been realized that relationships between buyers and suppliers can not be explained satisfactorily by the market mechanism alone (Axelsson and Easton, 1992; Håkansson and Johanson, 1992). Firms tend to develop more long standing and stable relationships of economic exchange that go beyond the single transaction. Uzzi (1997) has made a distinction between 'market relationships' that are similar to the arms-length ties as defined in economic reasoning, and 'close relationships', which are defined as embedded ties. An embedded tie is characterized by trust, fine grained information transfer, and joint problem-solving arrangements between the two actors.

Consequently, positioning a new venture in a business network also implies that adjustments have to be made with regard to the existing network structure. A new actor has to join in, additional activities have to be accommodated, and the exchange pattern and the distribution of resources have to change. There is a question of whether these alterations are limited to incremental network change or extend to radical network change (Halinen et al., 1999). Incremental network change is defined as a situation of continuous movement and adjustment with activity patterns essentially staying the same, while radical network change involves changes with regard to the 'deep structure' of the network. Deep structure, in turn, is defined as 'the fundamental choices which sets of business actors have made concerning who they are connected to’ (Halinen et al., 1999, p. 784). Moreover, the degree to which change is likely, as suggested by Uzzi (1997), depends on the number of embedded ties in the network. The more the network consists of embedded ties instead of arms-length ties, the more difficult it becomes to change the network structure.

This joining into an existing business network can also be looked upon as a learning process. This can involve learning at the level of the individual tie as well as at the level of the network as a whole (Håkansson and Johanson, 2001). Experiences gained with regard to one relationship can perhaps be generalized to other relationships, and capabilities to coordinate between different relationships can be enhanced (Håkansson and Johanson, 2001; Pahlberg, 2001). Besides, the nature of the learning situation is thought to depend on the type of dependency that characterizes the resource interface of a particular relationship (Silver and Wedin, 2001). In the case of a dependent resource interface, actors are dependent on a resource that is controlled by one particular actor in the network. Learning amounts to adapting to this form of dependency. In the case of interdependent resource interfaces, learning has more of mutual adaptation and exchange. Lastly, independent resource interfaces are characterized by some form of 'open' standard along which interaction takes place. Learning takes on the form of getting to know that part of the standard that applies to you. 
Taking the insights from the research into joint ventures together with the business networks perspective, the outcome of a new venture depends upon a learning process that has to turn into a positive feedback loop that amplifies initial achievements into durable success. The initial conditions hamper or facilitate the start up and especially the early stages of this learning process. Furthermore, the expectation is that a business venture only lasts if it succeeds in gaining a place in the business network. As a consequence, on a longer time frame, the learning process has to incorporate the establishment and maintenance of ties with a sufficient number of relevant actors, with the type of resource interface indicating what kind of learning is supposed to take place.

What needs to be investigated further, however, is the process itself. Initial conditions are favourable or unfavourable to a certain degree. Learning can take off in different directions, either acquiring knowledge about making it work or learning it cannot work. Although Ariño et al. (2001) have proposed this model of relational quality to explain the success and failure of a joint venture, knowledge about what actually is happening during a process that results in overcoming only some or perhaps all of the unfavourable conditions is relatively sketchy, especially with regard to the process of securing a position in an existing business network. The number and nature of ties a new venture needs to be able to position itself securely in the business network can be assessed, but that still leaves us with the question of what it takes to establish and/or change these relevant ties. It is only after questions about the what and how of the process itself are answered that questions about the why can be further addressed.

\section{SOCIAL BEGOMING}

The proposition here is to look at the process as a process of social becoming (Sztompka, 1991). Social process is defined as potential agency that actually is manifested in (inter)action. There are two ingredients that make this happen. On the one hand there is social structure, which shapes and is shaped by sequences of manifested action. On the other hand there are actors who act within the bounds of social structure but also find ways to defy structure. Putting this in the vocabulary of the business networks perspective, incremental and radical network changes (Halinen et al., 1999) are a result of a constant interplay between actors and network structure. Incremental network change is the outcome of the process whenever agency essentially conforms and stays within the bounds of the existing structure. When this happens, there is continuous movement and adjustment with activity patterns essentially staying the same. Radical network change happens when action goes out of bounds and effectively elements of structure are changed; consequently leading to new potential agency, with the resulting process taking a new turn. The learning part, then, can be taken as adjustment and adaptation on the part of the actors concerned in the case of incremental change, or 
(part-)creation of new (potential) agency and elements of structure in the case of radical change. In terms of Doz (1996), it is a matter of respectively the adjustment to essentially similar patterns or the creation of new patterns of thinking (the cognitive dimension) and acting (the behavioural dimension). It is a line of reasoning, which closely resembles Giddens' (1979) structuration theory.

To Sztompka, there are four levels of social structure, and each level refers to a specific sub-process of social becoming. The ideal level concerns 'the network of ideas, beliefs, images, [and] convictions about reality' (Sztompka, 1991, p. 124). In process terms, this level concerns 'the articulation of ideal structures (emergence and change of ideas, beliefs, images and their systems)' (Sztompka, 1991, p. 126). This is the level where Doz (1996) has concentrated on in his research on the outcome of joint ventures (see also Ariño and de la Torre, 1998; Ariño and Doz, 2000; Doz et al., 2000). The learning process, as he sees it, is predominantly aimed at arriving at a shared definition of the situation regarding the overall environment, the tasks at hand, the process of executing these tasks, the necessary skills, and the overall goal of the joint venture. To Anderson et al. (1994) and Halinen et al. (1999), firms who regularly interact develop shared network perceptions. This is something that has been identified by various other authors when they investigated commonly held beliefs about the nature of a sector or industry (e.g. Porac et al., 1989; Reger and Huff, 1993; Spender, 1989). Consequently, with regard to this level of social structure, the outcome of a new venture can be seen as being dependent on the establishment of a shared definition of the situation.

The normative level refers to 'the network of rules, norms, values and institutions prescribing the proper, expected conduct, and proscribing the wrong, forbidden modes of human action' (Sztompka, 1991, p. 124). The accompanying process is coined in terms of 'institutionalization of normative structures' (Sztompka, 1991, p. 126). This level has not received very much attention when it comes to strategic alliances and business networks. There is mentioning of 'fairness' when it comes to sharing the proceeds of a joint venture (Doz et al., 2000). Ring and Van de Ven (1994) have introduced the term of 'equity', understood as 'fair dealing', as one of the subjects of the learning process as well as an outcome of a successful joint venture. In a general sense, the normative level has gained wider recognition as a consequence of the rise of the new institutionalism approach (Powell and DiMaggio, 1991) and has been utilized in network research (Mizruchi and Galaskiewicz, 1993). Here organizations are thought to adapt to societal norms and values, although it has been suggested organizations actively engage in attempts to adjust the normative level to their own standards and needs (Oliver, 1991). Nevertheless, looking at this level of social structure, the outcome of a new venture can be seen as being dependent on the level of compliance to the preferred norms and values within the business network.

The third level refers to the interactional network. 'The form, shape or geometry of such interactional networks . . . significantly constrains or enables whether, 
toward whom, or with whom a person will act' (Sztompka, 1991, p. 125). With regard to process, this comes down to 'the crystallization of interactional structure' (Sztompka, 1991, p. 126). Doz (1996), concentrating on the dyadic relationship of two partners in a joint venture, refers to this as the interface design. For Uzzi (1997), this is a question of types of relationships in terms of embedded ties or arms-length ties. In the business networks perspective, the relational level is the point of departure for their argument. Starting with dyadic ties between business firms, they open up the horizon by drawing attention to the whole network of relationships in trying to explain why firms act the way they do (Anderson et al., 1994). The business network has become a research object in its own right with the recognition that it can be subject to incremental or radical change (Halinen et al., 1999). In conclusion, at this level of social structure the outcome of a new venture is dependent on the degree to which actual interaction is possible.

The fourth level is the opportunity level. This level refers to the 'vested interests' and 'variable access to valued resources or facilities', which both constitute the power configuration (Sztompka, 1991, p. 124). In process terms, this level is referred to as 'the allocation of opportunity' (Sztompka, 1991, p. 126). Zajac and Olsen (1993) have elaborated this level in terms of transaction costs and transaction value, emphasizing that partners in a joint venture not only have an interest in minimizing costs but also in maximizing gains. Doz (1996), in turn, talks about the efficiency, equity and adaptability of the joint venture, when it comes to discussing what both partners get out of it. It is also one of the fundamental premises of the business networks perspective that firms engage in relationships out of self interest (Anderson et al., 1994). Underlying the dyadic relationships are the interdependencies that have been put forward by the resource dependence perspective (Pfeffer and Salancik, 1978). Furthermore, the type of resource interface is seen to indicate the nature of the learning process in the case of collective innovation in a business network (Silver and Wedin, 2001). To sum up, at the opportunity level the outcome of a new venture is being affected by the vested interests and resource positions of the different actors concerned.

With regards to actors, Sztompka (1991, pp. 126-7) makes a distinction between individuals and collective agents. Individual agents can be: (type 1), 'common people in their normal, every day activities'; (type 2), 'individuals who by virtue of exceptional personal qualities ... act as representative of others'; or (type 3), 'those who occupy exceptional positions, endowing them with particular prerogatives'. Collective agents can be: (type A), 'directed solely at the members, taken in order to affect the members in various ways, to help, support, mould, or change them'; (type B), 'people get together, mobilize and act collectively to affect the wider society'; or (type C), 'kinds of bodies endowed with prerogatives to enact rules, laws, binding decisions on others'.

Within the business networks perspective, the emphasis is on collective actors (Håkansson and Johanson, 1992). The literature on joint ventures does mention 
individuals in certain instances whenever such a person plays his/her part as member, representative or manager of a collective actor (e.g. Ariño and de la Torre, 1998; Doz et al., 2000). The collective agents in the case of joint ventures and business networks, of course, are firms and other organizations. Even joint ventures can evolve into collective agents themselves when they are allowed to develop into a separate organization.

Furthermore, an additional type of collective actor can be added, as there are certain collections of actors that act similarly without some form of coordinated effort. For instance, buying behaviour of groups of customers can be similar enough to be able to make distinctions between particular markets or market segments. Also, interests of certain actors can be aligned in such a way that opposition against certain activities can follow a similar pattern, as if one is up against a single collective actor. This 'spontaneous collection of actors' is taken to be a fourth type of collective actor (type D). With regard to individual actors, type 1 refers to the persons that work at and/or are individual customers of these firms and organizations. Some individuals in management positions are type 3 and possibly can have the personal qualities to become a type 2 individual actor.

\section{DESGRIBING AND EXPLAINING THE SPORT7 FAILURE}

There is a deliberately built-in tension or contradiction between agency and structure in the theory of social becoming (Sztompka, 1991). This theory is what Van de Ven and Scott Poole (1995) call a dialectic process theory. On the one hand, structure is supposed to shape the course agency takes. On the other hand, regular patterns in agency constitute and maintain social structure and continuity, but also, in the case of defiant behaviour, agency can be the source of change. This means defiant behaviour potentially leads to tension, contradiction and conflict with regard to the social structure. As a result, the definition of the situation could have become ambiguous. The existing norms and values might have become subject to debate. Interaction could have taken place in a way that circumvents the current interactional network. Opportunities might have been opened up or closed down for certain actors. Or any combination of these four possibilities could have taken place. The moment such a controversy is resolved, either change has occurred or the old situation has been re-established.

Adding the theory of social becoming to the deliberations allows for a further reading of the process of a new venture trying to position itself in an existing business network. The expectation is that controversies will arise as a consequence of the start of a new venture. These controversies need to be settled in such a way that it allows for the new actor to establish and maintain the ties needed to survive. A description of the process amounts up to investigating these controversies and telling how they are settled eventually. The four levels of social structure distinguished above indicate where and in what terms these controversies can occur. 
Table I. Relationships overview

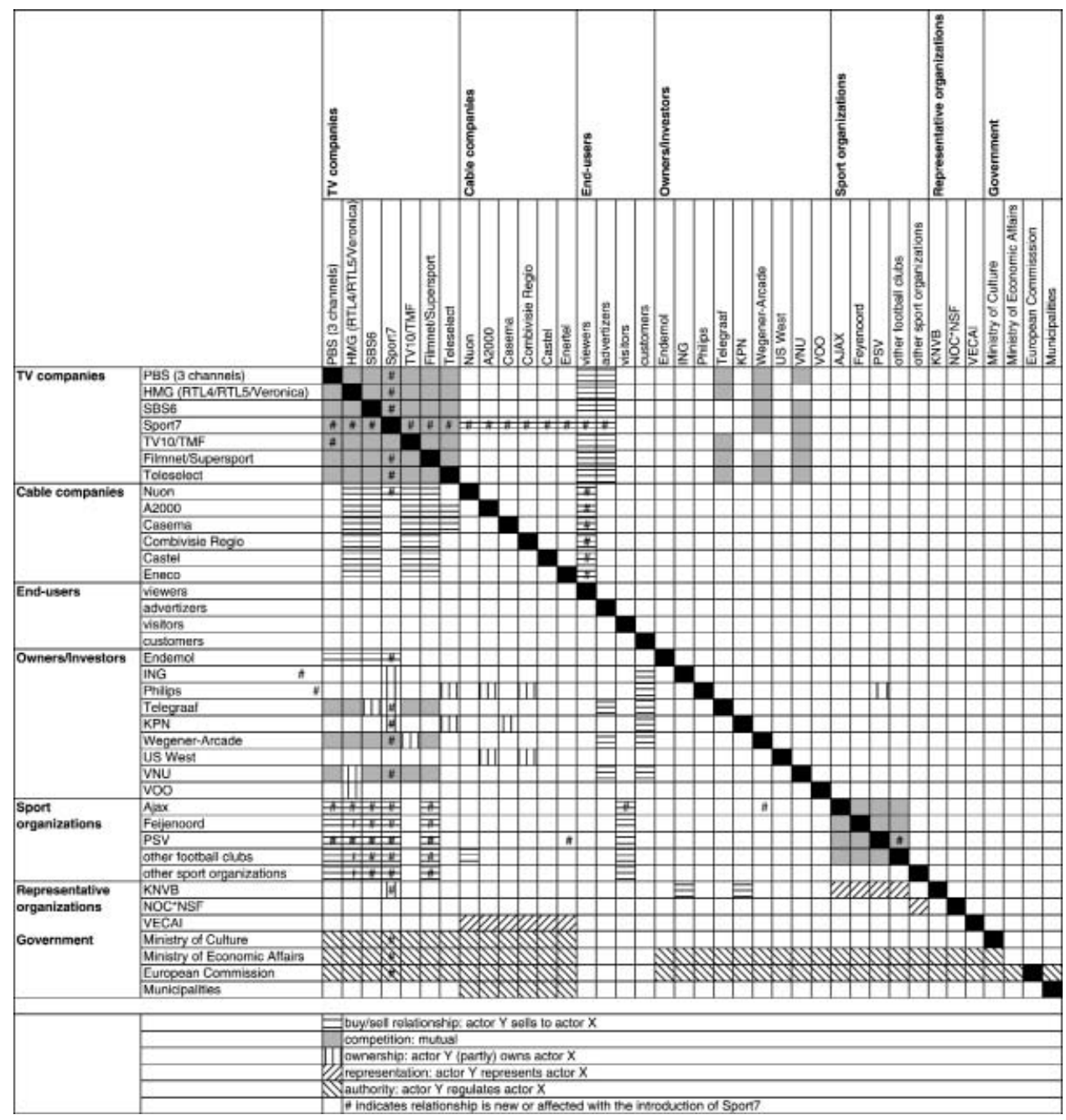

Consequently, any explanation why a new venture succeeds or fails has to concentrate on the reasons why the relevant controversies are settled in a particular manner, and to what degree these settlements have contributed to the outcome of this venture.

To do this in the Sport7 case, all the relevant actors were listed and their relationships explored. As it turned out, there were a number of different actors present in the business network. As is shown in Table I, these could be grouped into seven different categories. These categories are TV companies, cable companies, end-users, owners/investors, sport organizations, representative organizations, and government (for a more detailed description of each of the individual actors, see Appendix 1). The business network also contained five different types 


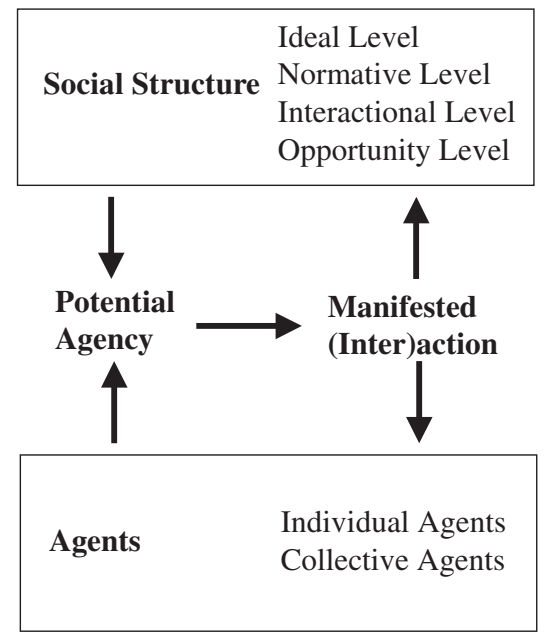

Figure 1. Process of social becoming

of relationships. Obviously there are buy/sell relationships and competitive relationships present. Some actors supply goods and services to others, in the course of which specific suppliers find they are competing against each other. Also there were relationships of ownership, representation, and authority. The consortium members, of course, (part-)own Sport7 but other holdings were present as well. A few organizations acted as representative bodies for particular groups of actors too. Finally, various government agencies oversaw the whole network, exercising their authority when they felt appropriate. Figure 1 gives a simplified overview of the business network.

With the start of Sport7, a number of these relationships came under pressure or had to be newly established. Relationships that were affected were taken as a starting point to try to see whether particular controversies could be detected. As it turned out, a grouping could be made around three areas of contradiction. These controversies will be described and typified below.

Controversies were looked for at each of the four levels of social structure. With regard to the normative level, the focus was on juridical activity by one of the actors as well as discussion over policy measures by one of the government agencies. These were both taken to indicate differences with regard to the expected normative order of things. Controversies at the ideal level were inferred from differences in describing a particular situation by the actors concerned. The interactional level was seen as being in disarray whenever the possibility for actual interaction was being hampered or blocked. Finally, controversy at the opportunity level was seen to take place whenever there was increasing rivalry, more active competitive positioning and/or disputing over resource allocation.

Data sources that are used here include a video taped documentary on Sport7, broadcast shortly after the Sport7 venture ended, a book analysing the Sport7 


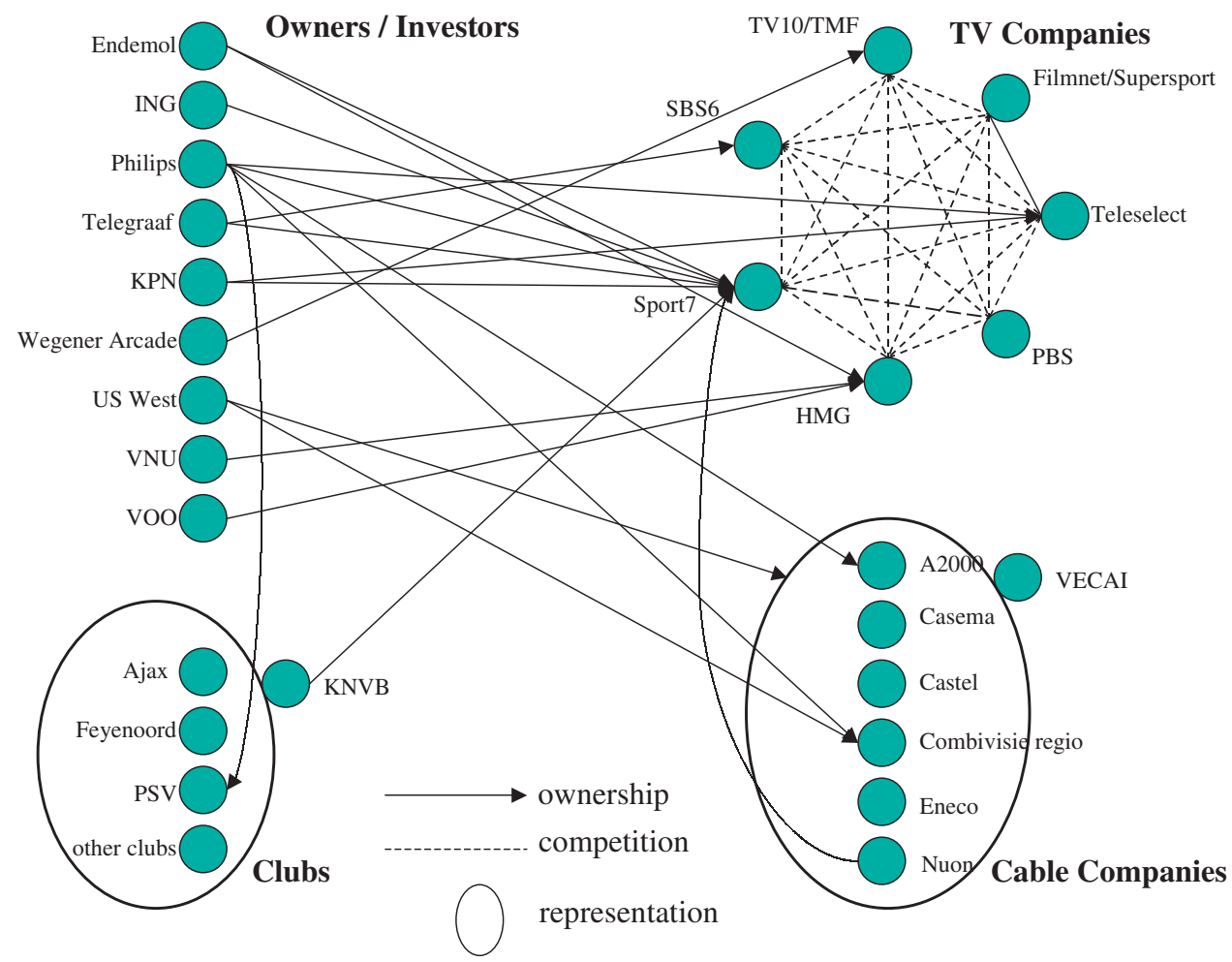

Figure 2. Relationship overview

failure (De Bruin et al., 1999), and a large collection of newspaper scraps reporting on the Sport7 case as it unfolded during 1996.

\section{BACKGROUND AND THREE AREAS OF GONTRADIGTION}

In 1995 and during the first days of 1996, with football club Ajax winning the European Champions League and the Dutch National Side preparing for the European Championships, football experienced a seemingly ever increasing popularity in the Netherlands. The contract between Dutch television and the Royal Dutch Football Association (KNVB) over the TV rights was up for renewal. The KNVB was expecting a record bid and had carefully designed a bidding procedure to maximize the proceeds. There were six contenders. The four commercial television companies joined the Dutch Public Broadcasting System (PBS), which traditionally had been the major sports broadcaster in the Netherlands. Besides, this time the production rights, also traditionally in the hands of the Dutch PBS, would be contracted out separately. Here, TV production company Endemol was a serious contestant. 
The first bid was expected to be handed in on 15 December 1995. In an attempt to secure the contract, the Dutch PBS and one commercial TV company had geared their bid and showed interest in complementary parts of the TV and production rights, amounting up to a little over 900 million guilders ${ }^{[2]}$ for the right to produce and broadcast football for seven years. After studying the various bids, the KNVB hinted to Dutch PBS that they should contact a second TV company to make a final joint offer. The others seemed to be out of the race. Then came the infamous press conference. The KNVB chairman announced that a consortium, of which the KNVB was a member, would start a new TV channel, dedicated to sports. This new sports channel was prepared to pay the KNVB an unprecedented 1040 million guilders for the right to produce and broadcast football for seven years. The other contenders were baffled.

In the meantime, as it appeared, TV production company Endemol had been able to round up a consortium of investors to back this new TV channel. Apart from Endemol and the KNVB, these were bank and insurance company ING, utility company Nuon, electronics company Philips, and one private investor. Part of the shares were kept in reserve for other cable companies to join in. This stake was thought to help persuade the other cable companies in the Netherlands to back this venture because their cooperation was an essential part of the plan. The idea was to have them pay 2 guilders per cable subscription per month. It was left to the cable companies to decide whether they would raise the subscription fee for a similar amount or find an alternative source to cover the costs. The 2 guilders per month, together with selling advertising time and merchandizing was seen to generate enough revenues to pay the KNVB for the TV rights and to make a profit. In this manner, Sport7 was launched as a new actor in the business network surrounding sports and television in the Netherlands.

With the signing of the deal between the consortium and the KNVB, not only Sport7 as a new actor, but also three controversies were added to the business network. Firstly, Dutch PBS were disappointed to say the least. Not only had they lost the broadcasting rights, they had gained a competitor. They also felt they were swindled as they thought they had reached some form of understanding with the KNVB that their bid would be looked upon as the most favourable one, only finding out later they had been outbid by a consortium of which the KNVB was a member. As a consequence, Dutch PBS started to prepare themselves for some severe rivalry and they threatened to start legal procedures.

Secondly, Sport7 still had to find a way to get their programmes to the viewer. It was not yet clear whether the cable companies were willing to transmit the new channel, and if they were, it was unclear under which conditions. At the time Dutch law prohibited any TV broadcasting through the air apart from the Dutch PBS. The plan was to charge the cable companies for transmitting the Sport7 programmes and leave them to decide whether they wanted to charge the subscribers. 
The Nuon cable company was a member of the consortium. Subscribers to this network were going to be charged the 2 guilders per month. The consortium had reserved part of the shares for other cable companies to join in. Nevertheless, the other cable companies were more inclined to charge Sport7 for providing transmission capacity instead of charging subscribers for additional channels. Charging TV companies had been the dominant business model in the Netherlands. Besides, if the cable companies were thinking of charging subscribers for content, they saw themselves more as competitors of the TV companies instead of buyers.

Thirdly, the major Dutch football clubs, and especially Feyenoord, opposed the deal the KNVB had made with the consortium. The viability of the venture was doubted as the Sport7 channel had not yet cleared access to the cable network. Also the top clubs felt shortchanged as the revenues which the KNVB as a seller to the consortium would receive, were divided up among the professional football clubs in such a way that, if the top clubs had sold the broadcasting rights of their games themselves, they felt they would have received more money. So here was a controversy within the ranks of the KNVB as a representative of the football clubs in the Netherlands, with Feyenoord insisting the KNVB did not have the right to sell TV rights on behalf of the Dutch professional football clubs; Feyenoord too was contemplating starting legal procedures.

These three controversies constitute the initial conditions at the start of the Sport7 venture. For Sport7 to succeed, these controversies needed to be settled in a particular manner. Sport7 had to conquer a viable competitive position next to the other TV channels, and especially Dutch PBS. Sport7 had to link up with the cable companies to secure access to the viewers under conditions that would make Sport7 profitable. Finally, the KNVB had to have the right to sell the TV rights on behalf of the Dutch professional football clubs reconfirmed, otherwise Sport7 would loose its major asset. Each of the three controversies will be discussed below. Table II lists the major events on a time axis and links these to the three controversies.

\section{FIRST GONTROVERSY: SPORT7 VERSUS PBS}

The PBS people were outraged when the KNVB chairman announced the TV rights would be sold to a dedicated sports channel, of which the KNVB was partowner as well. The PBS channels had much at stake. Football on television mostly produces good viewing rates. Also their production facilities would become redundant. They felt cheated, and as a reaction they almost immediately announced that they were starting legal procedures because they suspected this deal was against the rules of fair competition.

The Minister of Culture was worried as well. ${ }^{[3]}$ Firstly, if TV coverage of Dutch football moved from the PBS channels to Sport7 completely, a number of people would not be able to watch football on TV because they did not have a cable 
Table II. List of major events

\begin{tabular}{|c|c|c|c|c|}
\hline 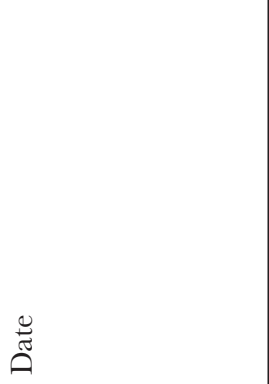 & 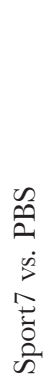 & 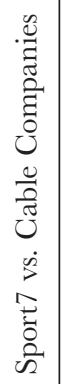 & 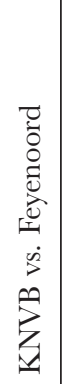 & \\
\hline 15 December 1995 & $*$ & $*$ & * & Deadline first bidding \\
\hline 10 February 1996 & $*$ & * & $*$ & KNVB press conference announcing sports TV channel \\
\hline 12 February 1996 & & * & & $\begin{array}{l}\text { VECAI chairman doubts willingness cable companies to } \\
\text { cooperate }\end{array}$ \\
\hline 12 February 1996 & * & & & PBS start legal procedures \\
\hline 12 February 1996 & & & * & Feyenoord votes against Sport7 deal in KNVB meeting \\
\hline 13 February 1996 & & * & & VECAI speaks against Sport7 conditions for transmission \\
\hline 19 February 1996 & $*$ & & & Statement from Minister of Culture on sub-licensing PBS \\
\hline 21 February 1996 & & $*$ & & $\begin{array}{l}\text { Dutch government lays out requirements for basic } \\
\text { package calbe transmission }\end{array}$ \\
\hline 24 February 1996 & & & * & Feyenoord makes KNVB ultimatum \\
\hline 27 February 1996 & & & * & KNVB does not answer ultimatum \\
\hline 4 March 1996 & $*$ & & & PBS and Sport7 start negotiations on sub-licensing \\
\hline 8 March 1996 & & & $*$ & KNVB and Feyenoord meet in court \\
\hline 15 March 1996 & & $*$ & & $\begin{array}{l}\text { Cable company A2000 willing to transmit Sport } 7 \text { as part } \\
\text { of an additional package }\end{array}$ \\
\hline 20 March 1996 & & & $*$ & $\begin{array}{l}\text { Verdict first court case: Feyenoord has to conform to } \\
\text { KNVB policies }\end{array}$ \\
\hline $\begin{array}{l}3 \text { April } 1996 \\
3 \text { April } 1996\end{array}$ & & $*$ & & $\begin{array}{l}\text { Sport7 announces free transmission for first three weeks } \\
\text { Negotiations started between Sport7 and individual cable } \\
\text { companies }\end{array}$ \\
\hline 1 June 1996 & $*$ & & & $\begin{array}{l}\text { EC Commissioner Karel van Miert announces } \\
\text { investigation }\end{array}$ \\
\hline 7 June 1996 & & * & & $\begin{array}{l}\text { Cable company Casema willing to transmit Sport7 for } \\
\text { free for first three weeks }\end{array}$ \\
\hline 19 June 1996 & & * & & $\begin{array}{l}\text { Cable company Castel and Sport7 agree on conditions } \\
\text { for transmission }\end{array}$ \\
\hline 22 June 1996 & * & & & PBS and Sport7 make deal on sub-licensing \\
\hline 3 August 1996 & & $*$ & & $\begin{array}{l}\text { VECAI advises members to transmit Sport7 for free for } \\
\text { first three weeks }\end{array}$ \\
\hline 18 August 1996 & $*$ & & & Sport7starts broadcasting \\
\hline 1 October 1996 & & $*$ & & $\begin{array}{l}\text { A2000 puts Sport7 behind decoder as part of an } \\
\text { additional package }\end{array}$ \\
\hline 23 October 1996 & & & * & KNVB and Feyenoord meet in court of appeal \\
\hline 24 October 1996 & & & * & Provisional ruling second court case: Feyenoord wins \\
\hline 28 October 1996 & & $*$ & & Sport7 extends free period to 1 January \\
\hline 29 October 1996 & & $*$ & & Cable company Eneco stops transmitting Sport7 \\
\hline 1 November 1996 & & $*$ & & Casema stops transmitting Sport7 \\
\hline 9 November 1996 & & & * & Feyenoord bans Sport7 cameras from own grounds \\
\hline 18 November 1996 & & & * & $\begin{array}{l}\text { KNVB proposition to change the bylaws; voting likens to } \\
\text { go against KNVB }\end{array}$ \\
\hline 21 November 1996 & & & * & KNVB board threatens to step down \\
\hline 7 December 1996 & $*$ & $*$ & & Sport7 Supervisory Board decides to stop \\
\hline 8 December 1996 & $*$ & $*$ & & Sport7 stops broadcasting \\
\hline
\end{tabular}




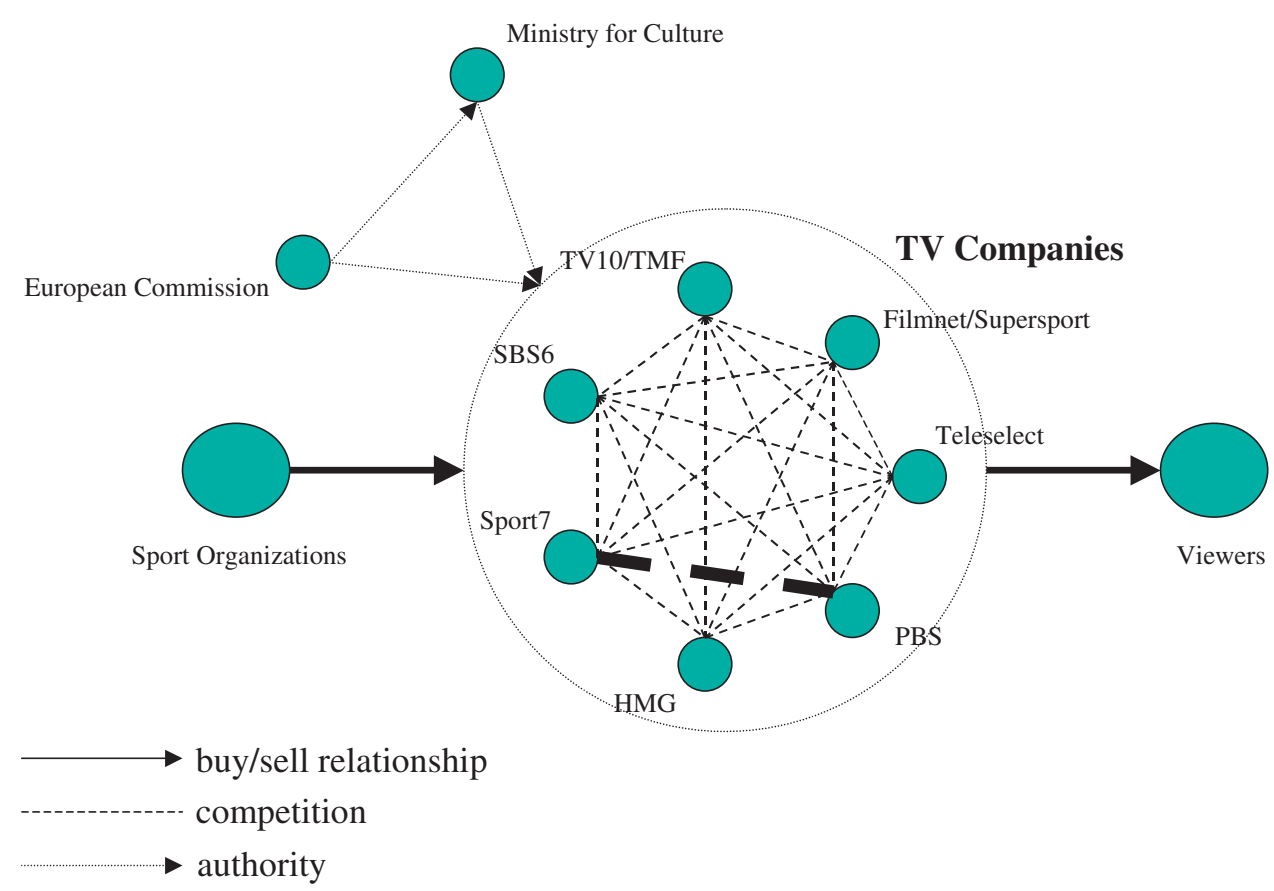

Figure 3. Sport7 vs. PBS

connection. Secondly, those who did have a cable connection were probably going to face an additional charge of 2 guilders per month. The Minister felt he had to safeguard a fair level of adequate sports information for all people at minimum cost. Thirdly, there was the issue of free collection of news. A journalist has a right to cover news events, and this might be at odds with the intention of restricting media access to football games. The Media Act gives the PBS channels a right to broadcast news and information on issues of national interests. Major sports events (football matches are considered major sports events) count as an issue of national interest. Fourthly, he also recognized there was a possibility of the KNVB and the cable companies joining together to monopolize football coverage on TV, which would be against national and European rules of fair competition. The Minister indicated that the chances of him stepping in depended on Sport7's willingness to sub-license some of the TV rights to the PBS channels. With regard to the fourth point, Euro Commissioner Karel van Miert announced he was going to investigate the Sport7 deal as there was a suspicion it violated European regulations. His ruling would also depend on the amount of sub-licensing.

The PBS channels and Sport7 started negotiations on mutual sub-licensing. Sport7 of course had bought the TV rights for football, but they also wanted to fill 75 per cent of their broadcasting time with other sports. The PBS channels possessed the TV rights of a number of other sports events, and Sport7 had interest in PBS's enormous archive of historical footage. Meanwhile, to bolster their 
positions, both parties tried to secure the TV rights of additional sports as well. The PBS channels closed deals with a number of smaller sports associations. Sport7 also acquired TV rights of a number of foreign sports events. On 22 June, both parties came to an agreement, settling who could broadcast what at which time.

The PBS channels also decided to compete with Sport7 head on. After Sport7 had started broadcasting, the PBS channels increased the amount of sports coverage as well. They also started a publicity campaign to acquire the viewing public's sympathy. Their most popular sports programme, Studio Sport, was accompanied by a trailer with the slogan 'of everyone - for everyone'. ${ }^{[4]}$ This was an attempt to foster a hostile attitude against Sport7 because a large number of viewers felt football had been taken away from them. This slogan amplified a feeling among viewers that Sport7 wanted to charge 2 guilders per household for sports coverage on TV that previously had been provided for free. The initiators of Sport7, on the other hand, explained that their way of exploiting these TV rights was the only safeguard for keeping football on TV in Dutch hands and offered at a reasonable price because they forecast that these rights eventually would end up in the hands of a global media conglomerate with viewers having to pay much more than 2 guilders per month for watching football on TV.

Besides, Sport7 boasted that their programmes were going to be innovative and better than anything the PBS channels had ever done before. This latter claim, however, turned against them because most viewers refused to agree, and the notion of 'Sport7 quality' acquired an ironic ring to it. As a consequence, the Sport7 viewing rates were much lower than expected, which of course affected advertising revenues. By October, KNVB and Sport7 officials were saying that Sport7 sports coverage was not as good as initially was hoped for, but this was due to start up problems which would be ironed out in the near future. Also one wanted to renegotiate the sub-licensing deal with the PBS channels because Sport7 had apparently been to generous; allowing the PBS channels to compete at this level. It never came to that. On 7 December the supervisory board of Sport7 pulled the plug. Sport7 would stop broadcasting the next day.

At the opportunity level, the sub-licensing deal eventually defined part of the competitive relationship between Dutch PBS and Sport7. The controversy was settled in terms of regulating mutual access to the resources relating to their broadcasting materials. Additionally, at the normative level the same deal reconfirmed the special position of Dutch PBS in the Netherlands as the deal was prompted by the Minister for Culture who actively enforced the Media Act. Besides, the European Commission was monitoring the situation for possible breaches of the rules on fair competition. Furthermore, with regard to their mutual competitive position in terms of viewing audiences, the tip of the scale balanced towards Dutch PBS, aided by a hostile attitude among Dutch viewers towards Sport7 and the failure of Sport7 to deliver the high quality programming that was promised. 
Apparently, Sport7 had violated a norm held by the Dutch viewing public that football coverage on TV should be part of the public domain. This left Sport7 holding on to the short end of the stick; contemplating ways of opening up the negotiations once more, when the venture was being ended.

\section{SEGOND GONTROVERSY: SPORT7 VERSUS GABLE GOMPANIES}

The Sport7 venture counted on two main sources for revenues. According to the business plan, the biggest source was advertising. ${ }^{[5]}$ Next came the 2 guilders per month, which the cable companies had to pay for every connection. The consortium was confident that the cable companies would not hesitate to pay these 2 guilders, hinting that the cable companies could raise the subscription fee for a similar amount. They even reserved 15 per cent of the shares in the new company for cable companies to pick up, so they could benefit from the venture as well. The Nuon cable company was already one of the shareholders, and the expectation was that the other cable companies willingly would join in.

Nevertheless, in an initial reaction on 12 February, the chairman of the association for cable companies in the Netherlands (VECAI) doubted whether the cable companies would join in. ${ }^{[6]}$ In their view, there were three types of TV channels.

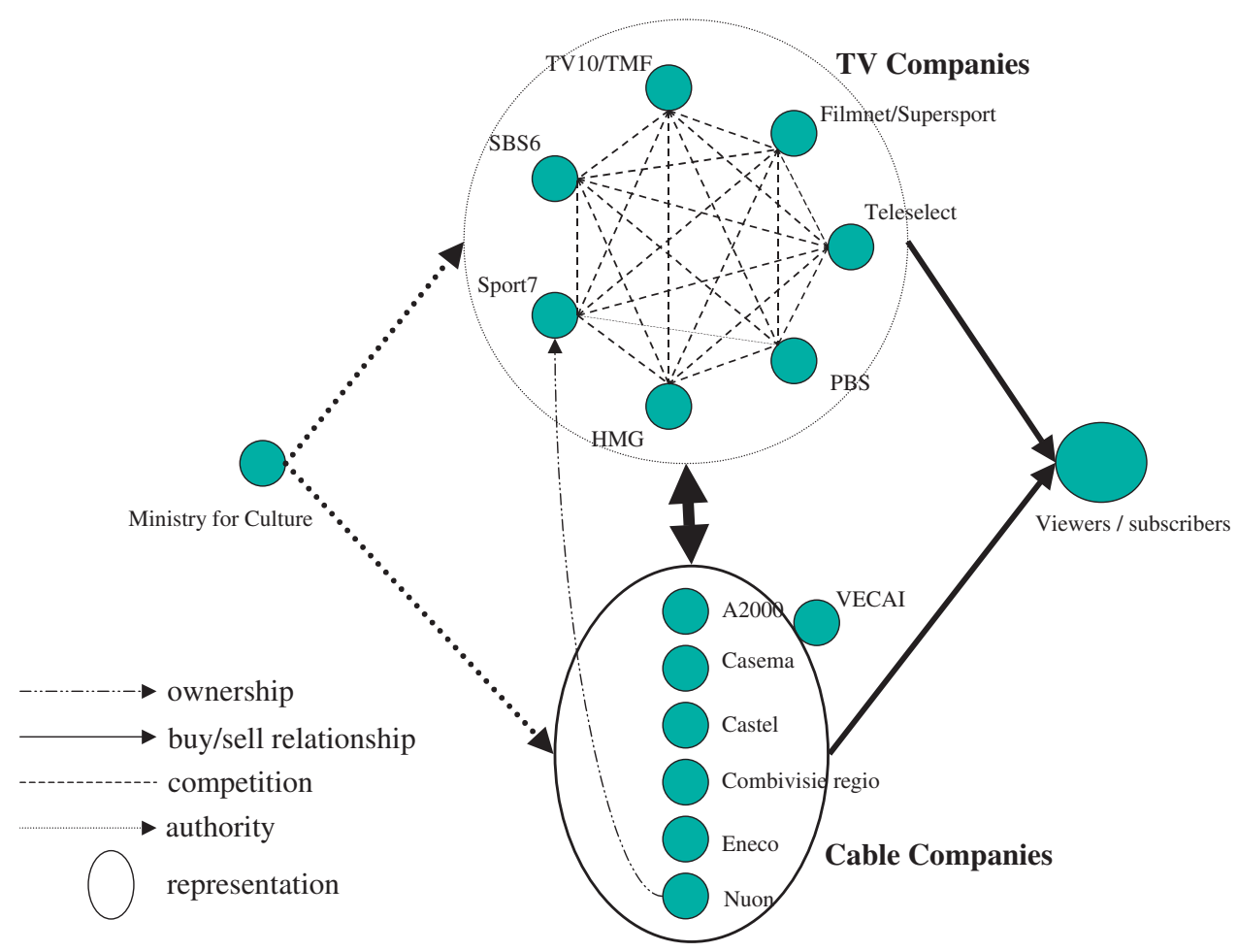

Figure 4. Sport7 vs. cable companies

(C) Blackwell Publishing Ltd 2003 
Firstly, there were PBS channels which were transmitted at cost, paid for by the subscription fee. Secondly, there were open commercial channels that paid the cable companies for transmission. Thirdly, there were pay channels for which the viewer had to have an additional subscription and a decoder to be able to watch. These pay channels also had to pay the cable companies for transmission. This definition of the situation was about to change a little, prompted by possible new legislation. The Dutch government was working on a revision of the Media Act. They were thinking of defining a basic package, consisting of a number of TV channels that were considered essential for the Dutch viewer to be able to watch. This basic package was expected to be transmitted by the cable companies at cost. That would open up the possibility for the cable companies to offer additional packages to their subscribers at extra charge. The VECAI chairman speculated, following the logic of the cable companies, that Sport7 had a choice. They could become an open commercial channel that paid the cable companies for transmission. Or, if they wanted to have 2 guilders per subscription per month, they should become a pay channel and charge the cable subscribers directly, while still paying the cable companies for transmission. In the near future, there was a possibility for Sport7 to become part of some additional package under terms that had to be negotiated.

Indeed, the VECAI board spoke against paying the 2 guilders per month for every cable connection the next day. Some of the cable companies declared that they were willing to negotiate on the terms of transmitting Sport7 as part of a possible future additional package. The cable companies very much feared that if they became part of a commercial TV channel and collected money on behalf of that channel, other commercial TV channels might start asking for money as well. The cable companies preferred it the other way round. The government spoke out on the matter soon after that on 21 February. They wanted the Dutch and foreign PBS channels to become part of a legally required basic package. What happened to the commercial channels was a matter that had to be decided in consultation by the cable companies themselves and local government, which often still had a say in what was going to be transmitted. Basically, commercial TV channels would be faced with the choice described above. However, the actual introduction of additional packages would have to wait until sufficient decoders would become available in the Netherlands. Besides, only 30 per cent of the cable connections were capable of supporting a decoder. The expectation was that it would take some time before the cable network was technically ready.

This attitude of the cable companies was a severe setback for Sport7. Either they paid the cable companies for transmission instead of the cable companies paying them 2 guilders per month for every cable connection, or they became a pay channel or part of an additional package - but that would very likely decrease the number of subscribers. Research by the University of Amsterdam indicated that 80 per cent of the viewers were not prepared to pay for a decoder to receive 
Sport7. ${ }^{[7]}$ Only Nuon was willing to collect the 2 guilders per connection per month, but this company was owned by a member of the consortium.

Sport7 had planned to start broadcasting on 18 August. On 3 April, Sport7 announced that they would allow transmission for free for the first three weeks. They started negotiations with individual cable companies to see whether they would take up the offer. In the meantime, one cable company stated that they were ready for introducing additional packages. Commercial TV channels could be added to the basic package if they were willing to pay the right price. Two other cable companies agreed to transmit Sport7 for free while waiting for further developments. Finally, on 3 August, the VECAI agreed to advise all other cable companies to transmit the programme for free until sufficient decoders became available. As it appeared, almost every cable subscriber would be able to watch Sport7's first broadcast on 18 August.

On 28 October, Sport7 announced it would extend the free period until 1 January. Nevertheless, one cable company had put Sport7 behind a decoder in an additional package from 1 October onwards. ${ }^{[8]}$ Other cable companies stopped transmitting Sport7 at all, as they felt they could utilize their limited transmission capacity better. This meant that a decreasing percentage of the cable subscribers had the ability to watch Sport7 for free, if at all. On 7 December, the supervisory board of Sport7 pulled the plug. Sport7 would stop broadcasting the next day.

Again this was a controversy that was characterized by negotiations, but this time these were more haphazard. The conflict hinged on the ideal level, as both Sport7 and the cable companies had different definitions of the situation. They both went into the negotiations as sellers. Sport7 tried to sell TV content while the cable companies were in the business of selling transmission capacity. In the meantime at the normative level, the Dutch government was working on changes in the Media Act that would alter the circumstances under which cable transmission was going to take place. By allowing the introduction of additional packages, in turn, the cable companies were given the upper hand with regard to the opportunity level, as effectively they could decide which channel was going to be transmitted under what conditions.

For Sport7, the only way around this was a sort of popular demand in case viewers insisted a particular commercial TV channel had to be transmitted regardless. Judging by the popularity of Sport7 with the Dutch viewers, as has been put forward above, this was unlikely to happen in the short run. Besides, at the interactional level there were technical limitations that also affected possibilities for interaction between TV companies and their viewers through cable networks. Eventually, back at the ideal level, the definition of the situation in which the cable companies were the sellers and the TV companies were the buyers acquired dominance and Sport7 had to give in. With regard to this point, Sport7 were forced to learn the hard way about the appropriate definition of the situation, and the interests they were up against. Sport7 ran into barriers that were present at the 
ideal and opportunity levels. The cable companies had defined their interests in terms of protecting and expanding their position as sellers of transmission capacity in the business network. Aided by developments at the normative and interactional levels, they were able to strengthen that position at the expense of Sport7.

\section{THIRD GONTROVERSY: KNVB VERSUS FEYENOORD}

Almost immediately after the press conference on 12 February, in which the KNVB announced the establishment of a new TV sports channel, it appeared that the Ajax and Feyenoord football clubs were against the deal. Later that month, in a KNVB meeting, during which the clubs had to approve the deal, four football clubs including Feyenoord did not vote in favour. They doubted the financial base of the new venture, especially as it appeared to them that Sport7 would probably disappear behind a decoder, limiting the viewing potential considerably, and negatively affecting revenues from both advertising and viewers. Besides, although the deal was approved in that meeting on a majority vote, the Feyenoord chairman doubted whether the KNVB actually had the power to sell the TV rights. He believed that the clubs own the TV rights, and Feyenoord had never given the KNVB permission to sell the TV rights on their behalf.

Immediately after the meeting, Feyenoord contemplated starting legal procedures against the KNVB to try to clarify who actually had the power to sell the TV rights. Although the deal brought an unprecedented amount of money in the hands of the football clubs, the top clubs in the Dutch league felt shortchanged. In their view they subsidized the lesser clubs because they attracted larger crowds and more viewers, and this was only partly reflected in the distribution code. The top clubs did subscribe to a form of solidarity among all the professional football clubs in the Dutch league, but discussion remained on how much this principle should cost them. Besides, the top clubs expected that there were even more and bigger deals to be done in the near future on a larger European scale, and they

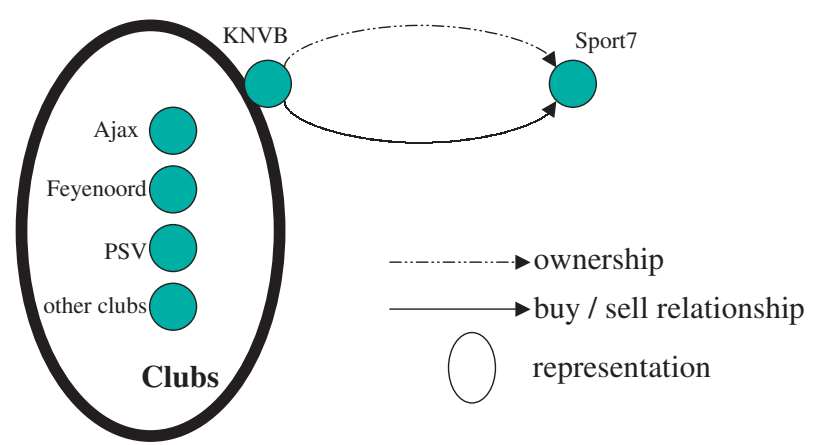

Figure 5. KNVB vs. Feyenoord 
did not want to have their hands tightened too much. The KNVB on the other hand, and also the majority of the clubs, thought the Sport7 deal was the best they could get. Especially as the KNVB was part of the consortium as well, they felt more in control because they were able to directly influence how football was treated on television.

Feyenoord in fact proceeded and gave the KNVB an ultimatum. Feyenoord announced they were going to start summary proceedings against the KNVB, unless the KNVB would make a statement before 27 February, 12:00 noon, declaring that the TV rights of Feyenoord's home games were owned by Feyenoord. Sixteen other clubs in the Dutch league appealed to Feyenoord in an open letter to stop resisting the deal. The KNVB did not answer the ultimatum, and Feyenoord and the KNVB met in court on 8 March. The verdict came 12 days later on 20 March. In the meantime, the other two top clubs had joined Feyenoord, telling the KNVB in writing that they wanted to sell their TV rights themselves. The judge ruled in a temporary injunction for Feyenoord to conform to KNVB policy because Feyenoord is a member of the association, and therefore has to submit to it.

The Feyenoord chairman did not feel defeated and announced he would now embark on full legal action. Not only did he announce that he would appeal against this verdict, he also said he wanted to file a complaint against the KNVB with the Ministry of Economic Affairs and the EC because of what he felt was cartel-like behaviour on the part of the KNVB. He simply wanted to defend his rights and to know where Feyenoord stood in this matter, he declared. ${ }^{[9]}$ The appeal finally appeared in court as late as 23 October. In the meantime, Sport7 had started broadcasting. A provisional judgement was made the following day. The judge ruled that Feyenoord had the right to prohibit cameras to record home games. Because of the complexity of the matter, a final judgement was postponed until 8 November. That day, the judge only made another provisional judgement, this time adding that, according to the KNVB bylaws, the home side has the right to prohibit live broadcasts of their games. The final judgement was now expected on 20 December. The judge did appeal to both Feyenoord and the KNVB to try to settle the conflict out of court before that date.

The fact that home sides had the power to prohibit live broadcasts of their games meant that the KNVB could not keep to the terms of the contract with Sport7. Realizing the devastating potential to the whole venture, the KNVB immediately scheduled a meeting to discuss a proposal to change the bylaws with regard to this matter. Feyenoord exercised their rights and forbade a live broadcast of the next home game. Ironically, Sport7 had sold this game to one of the TV pay channels. The latter immediately claimed compensation for Sport7 failing to deliver. At the KNVB meeting on 18 November, the actual proposition was put to the members. Voting on the change of the bylaws was scheduled for the meeting on 8 December. On 21 November, in a letter to the members, the KNVB execu- 
tive board threatened to step down if the proposed changes in the bylaws were not approved. This time not only did the professional football clubs have to vote in favour, but also the amateur part of the KNVB. The board needed a two thirds majority to succeed. In the meantime, Sport7 threatened to sue for compensation if the KNVB failed to keep to the terms of the contract. Feyenoord and the KNVB were unable to compromise. By 5 December, the amateur part of the KNVB appeared to be mostly against the proposition. On 7 December, the supervisory board of Sport7 pulled the plug. Sport7 would stop broadcasting the next day. The KNVB executive board stepped down the same day.

Interestingly, this is a controversy that only indirectly affected Sport7, as it mostly concerned the KNVB, who was one of the consortium members as well as the main supplier of TV rights. Nevertheless, the way this controversy was developing did help to bring down the Sport7 venture. It started at the opportunity level as a conflict of interests between the KNVB and the top clubs, with Feyenoord leading the battle. It quickly spread to the normative level when the right to sell TV rights by the KNVB was being disputed and legal procedures were started. This in turn affected the interactional level in two ways. Firstly, the buyer-supplier relationship between the KNVB and Sport7 became unsettled, as it was starting to look like the KNVB had nothing to sell. Secondly, the representative relationship between the KNVB and the football clubs was in disarray as the clubs lost confidence in the KNVB and especially the executive board as their representative body. The controversy was not completely settled before the Sport7 supervisory board decided to put an end to the Sport7 venture. What had happened was that the KNVB ceased to be an effective actor as they were in the process of losing their most valuable resource, viz. the TV rights, and their mandate to act on behalf of the clubs they represented. With this hanging over their head, the Sport7 resource position, in turn, was in jeopardy indeed.

\section{DISGUSSION AND GONGLUSION}

The combined effect of the three controversies described above made the consortium members loose faith in the viability of the Sport7 venture. The unwillingness of the cable companies to cooperate deteriorated the earning potential of Sport7 considerably. It turned out that Sport7 was unable to collect the 2 guilders per cable connection per month. At most, there was a possibility that Sport 7 could collect a small fee per connection, but only from those cable subscribers that opted for an additional package. At worst, Sport7 had to pay the cable companies for transmission instead of being paid for offering a programme. Besides, the competition between Sport7 and the PBS channels had a devastating effect on Sport7's popularity. This affected the viewing rates, which in turn had consequences for Sport7's position in the advertising market and the willingness of viewers to pay an additional charge for receiving the sports channel. Finally, when it appeared 
the agreement between the KNVB and Sport7 was based on legal quicksand, as the Feyenoord versus KNVB court case would show, the decision to stop was readily made. Looking at the three controversies separately, two of the three ended up in a settlement that was unfavourable for Sport7, while the third one seemed to go against Sport7 when the venture was being ended. It is the way in which these controversies were settled that explains the outcome of the Sport7 venture.

The three controversies have been analysed here as separate processes. However, mutual influences are traceable in the course of events, leading to an image of 'interacting vicious circles' denying Sport7 its existence. The problems Sport7 encountered in accessing the viewers through the cable network and the initial outcome of the competitive battle between PBS and Sport7 strengthened Feyenoord's conviction that Sport7 was not going to be a viable business, thereby fuelling the club's determination to oppose the KNVB and gaining support among other KNVB members. Besides, the bad image of Sport7 among the Dutch viewers was partly prompted by the 2 guilders per connection per month that Sport7 wanted from the cable companies. This, the Dutch viewers felt, was a ploy to eventually charge them for something they always had had for free. It weakened the competitive position of Sport7 in relation to Dutch PBS by affecting the viewing rates, and bolstered the position of the cable companies as there was little fear of a popular demand for the transmission of Sport7.

Both the research into joint ventures and the business network perspective have captured the process in terms of learning. To the joint venture researchers, the initial conditions, as well as the other three elements of relational quality hamper or facilitate the process (Ariño and de la Torre, 1998; Ariño and Doz, 2000; Ariño et al., 2001; Doz, 1996; Doz et al., 2000). When learning does take place, the cooperation process turns into a kind of positive feedback loop, amplifying initial achievement into greater success. Taking the theory of social becoming as a point of reference, the joint venture research has put the emphasis on the ideal level of social structure. Here the interactional, normative and opportunity levels have been added, allowing for a process analysis that looks at learning not only as arriving at a shared definition of the situation, but also as agreeing on acceptable norms and values, as opening up interaction possibilities, and as compromising with regard to differences in opportunities and interests as well. The Sport7 joint venture partners have indeed acknowledged that learning at all these levels had taken place, only it was not the type of learning that comes with the above mentioned positive feedback loop. They learned that Dutch PBS could not be circumvented and they had to accept a sub-licensing deal that eroded their resource position substantially. ${ }^{[10]}$ They learned that their original proposal to gain access to the cable network was not going to be accepted, so they had to make adjustments. ${ }^{[1]}$ Finally, they learned about the fragility of their resource position when the KNVB started to crumble under the opposition from the clubs. ${ }^{[12]}$ 
Looking at learning from a business network perspective point of view, the Sport7 case highlights another interesting phenomenon. It seems that the KNVB, with the other partners in the Sport7 venture took the business network as being characterized by 'dependent resource interfaces', with the TV rights being the essential resource here (Silver and Wedin, 2001). On this basis, Sport7 was introduced by them as the central actor; expecting the others to enter a learning process of adaptation to their mode of operation. However, most of these other actors entered the process more with an 'interdependent resource interfaces' frame of mind. As it appeared, Sport7 themselves were forced to learn by way of adjustment and adaptation; eventually finding it impossible to sustain a viable position in the network. It is by adding the theory of social becoming that an analysis of how one learning mode gains dominance over another can be made. It is by looking for the controversies and describing their settlement that an explanation can be found.

In essence, this paper is an experiment of thought. It is an attempt to describe and explain the failure of the Sport7 TV channel. The possible wider significance concerns the theoretical line of thought, which has been developed here. Its usefulness has been demonstrated here in explaining the Sport7 failure, which in turn allows for some generalization to the theoretical propositions put forward in this paper (Yin, 1989). This line of thought might also inform further research into the outcome of business ventures. As Doz (1996) concluded, the strategy process is neither static or dynamic, nor teleological or emergent, but is better seen as selfadjusting and adaptive. Looking at it as a process of continuity and change in terms of the development and settlement of particular controversies, might be a fruitful option. In this case, it did lead to a description and explanation of how and in what way the Sport7 venture failed. However, the actual reasons why Sport7 failed are found in the particularities within the case. Following the theoretical line of thought that has been put forward here, the why with regard to the outcome of new ventures can be further addressed. Research, then, should probe into more general reasons why controversies are settled in a particular manner.

Building on this line of thought, one issue that could be investigated further concerns the question why some controversies lead more to a situation of winners and losers, as was the case with the three controversies here, while other controversies lead more to compromises with each actor involved getting something out of it. Work has already been done that focused on the particular negotiating strategies that can be employed (e.g. Axelrod, 1990; Bazerman and Neale, 1992; Fisher et al., 1990). Looking at the Sport7 case, the outcome might have something to do with the 'depth' of the controversy. Although to Sztompka (1991), all four levels of social structure are equivalent, some form of hierarchy could exist here. In those instances in which a controversy only concerns the opportunity level, the actors involved can more easily reach a compromise. Whenever the controversy deepens to the other levels of social structure, as was the case here, it seems that the conflict hardens, and it can only be resolved if one side is able to overpower the other side. A conflict of 
interests normally occurs between two actors in a network. To settle this type of conflict, only some mutual adjustment is required, or as Lundgren (1992) put it: a process of coordination leading to incremental change. When the conflict deepens to other levels of social structure, more actors in the network need to be mobilized, possibly leading to a more radical change (Halinen et al., 1999; Lundgren, 1992), but also leading to settlements with clear winners and losers.

Another question arising out of this analysis has to do with the 'width' of the changes that were needed for Sport7 to succeed. For one, the mobilization of more actors as a consequence of the 'depth' of a controversy might stir a number of other potential controversies to come to the surface. Besides, as for the learning experience, Sport7 suffered setback upon setback, but there were no less than three controversies that had to be settled. For the Sport7 supervisory board, it was not only the succession of setback upon setback, but also the fact that there were three controversies that had to be settled, which made them lose faith. Besides, as was explained above, these three controversies also had a bearing on each other. It still remains a question whether each of these controversies on its own could have brought down Sport7, or if it was the combination of the three that made it a failure. Taking this image of 'interacting vicious circles' mentioned above, a combination of unfavourable settlements might have a disproportionally larger negative effect on the outcome of a new venture than just one unfavourable settlement on its own. Again this requires further research.

To sum up, any new venture will give cause for conflict or contradiction in the business network. How these controversies are settled determines the outcome of a new venture. In the case of Sport7, the settlement of the three controversies appeared to go against it. With regard to the settlement of controversies in general, some interesting questions can be put forward. What will be the effect of 'depth', of having to reach compromises at the opportunity level only, or are the other three levels of social structure going to be involved as well? Or will it be a question of 'width', of having to work your way through to many controversies that explains the outcome in cases like these? Or will it be a combination of the two? These are questions that can be further investigated. What can be concluded at this point, however, has to do with planning new ventures like the Sport7 TV channel. For judging the chances of a successful outcome, it seems fruitful to try to assess the number and nature of the controversies that probably will arise as a consequence of the attempt to gain a place in the business network. By doing this, the initiators at least know what they are up against.

\section{NOTES}

*I wish to thank the five anonymous reviewers of the Fournal of Management Studies for their comments on earlier versions of this article. The first version of this article was presented to the Sub-theme on Inter-organizational Relations and Networks: Methodologies and Theories, 15th EGOS Colloquim, University of Warwick, 5-6 July 1999. 
[1] Translated from KNVB press conference, as repeated in PBS TV programme Reporter.

[2] $f 2.20371=€ 1.00$.

[3] Based on a letter to parliament by the Minister for Culture, dated 2 February 1996.

[4] Translated from Dutch.

[5] De Bruin et al. (1999, p. 34).

[6] The shares that initially were reserved for the cable companies were later picked up by the privatized Dutch mail and telecommunications company KPN. The private investor sold his shares on to newspaper publisher De Telegraaf.

[7] De Telegraaf, 7 March 1996.

[8] Much to their dismay, Sport7 was put in an additional package with an adult channel and a Chinese comedy channel.

[9] De Telegraaf, 27 February 1996.

[10] This was stated by Henk Kivits, chief executive of Sport7 (NRC Handelsblad, 9 December 1996), John de Mol, chief executive of Endemol (NRC Handelsblad, 17 December 1996), and Peter Vogelzang, chief executive of the KNVB (NRC Handelsblad, 27 December 1996).

[11] Later Jos Staatsen, chairman of the KNVB (De Telegraaf, 27 December 1996), as well as Peter Vogelenzang, chief executive of the KNVB (NRC Handelsblad, 27 December 1996) considered this a severe setback. John de Mol, chief executive of Endemol (NRC Handelsblad, 17 December 1996) and Henk Kivits, chief executive of Sport7 (NRC Handelsblad, 9 December 1996) treated this more as a hurdle, which after it emerged could not be taken, had to be circumvented.

[12] John de Mol, chief executive of Endemol (NRC Handelsblad, 17 December 1996) described the demise of the KNVB in this matter as having the effect of the disappearance of the light at the end of the tunnel.

\section{APPENDIX 1}

Overview of actors

\section{TV companies}

The number of Dutch TV channels has grown substantially during the past few years.

Originally, there only was a public broadcasting system. This has been supplemented with a number of commercial operators.

\section{Gable companies}

The three PBS channels are broadcast through a number of $\mathrm{VHF} / \mathrm{UHF}$ transmitters. All the other TV channels can only be received through cable. In the early days, every household had its own antenna on the roof and was able to receive these three channels. During the 1970s and 1980s, municipalities adopted a policy against roof antennae and started to construct cable networks. In this way, a large number of cable companies were established which were local government owned. These were later sold off, and in 1996, most of these local cable networks were linked up and owned by a regional operator. The 15 largest cable companies in 1996 had a market share of $76.1 \%{ }^{1}$
Public Broadcasting System (three channels)

$H M G$ (RTL4, RTL5, Veronica)

Wegener Arcade (TV10, TMF)

SBS6

Filmnet/Supersport pay channels

Teleselect pay channel

Nuon operates a cable network in the East and the North of the Netherlands.

A2000 operates a network in the Amsterdam area.

Casema operates a network in the West of the Netherlands.

Combivisie Regio operates a network in the South of the Netherlands.

Castel operates a network in the Northeast of the Netherlands.

Eneco operates a network in the Rotterdam area. 


\section{End-users}

\section{Owners/investors}

In 1996, there were a number of companies who had reasons to invest in TV companies and/or cable companies. A number of them had commercial interests in football clubs as well. The consortium of investors in Sport7 initially consisted of the Royal Dutch Football Association (KNVB), television production company Endemol, bank and insurance company ING, cable company Nuon Telekabel, electronics company Philips, and one private investor. The private investor sold his share to publisher Telegraaf in early April, while the share which was reserved for other cable companies was picked up by the privatized Dutch mail and telecom company KPN.
Dutch viewers

The biggest group are those viewers who have a cable subscription and enjoy an offering of on average 27 channels.

A smaller group, mostly living in remote areas, has to rely on their own antennae. These viewers are able to receive the three Dutch PBS channels, and the Flemish and German PBS channels, depending on which part of the country they live in. Some of these viewers have bought their own satellite dish and receiver, but this is not a very widespread phenomenon.

There are viewers who enjoy visiting sports events as well. So the group of viewers contains a subgroup of sports fans that visit sports events.

\section{Advertisers}

Both the PBS channels and the commercial channels sell advertising slots between the programmes. So they compete for the same advertising guilders.

Endemol used to have a share in HMG (owner of TV channels RTL4, RTL5, and Veronica).

$I N G$ was a major sponsor of the KNVB.

$K P \mathcal{N}$ sponsered the KNVB as well, and has entered a joint venture with Philips (Teleselect).

$\mathcal{N}$ uon was a privatized electricity company, which had branched out in other utilities and also sponsered the football clubs Vitesse and Heerenveen.

Philips also had entered joint ventures with US West (this joint venture owns the cable companies A2000 and Combivisie Regio), and KPN (the pay TV channel Teleselect). Besides, Philips is associated with football club PSV.

Newspaper publisher Telegraaf also was part owner of TV channel SBS6.

Publisher $V N U$ had a stake in HMG. 


\section{Sport organizations}

\section{Interest groups}

Publisher/record company Wegener-Arcade owned TV channels TV10 and TMF. Nethold owned the pay TV channels Filmnet and Supersport. ${ }^{2}$

Dutch professional football clubs are of course the first that spring to mind. They compete in two national leagues. The top league consists of 18 clubs and the winner is the Dutch football champion. The second league consists of 18 clubs as well. Besides, there is a national cup that works with a knock out system in which all the professional clubs compete together with the national amateur football champions. The major contenders for national championship and the national cup are Ajax, Feyenoord, and PSV.

Because Sport7's ambition was to become a dedicated sports channel and not a football channel exclusively, other sports organizations are important as well. These are the equivalents of the football clubs but in other sports. Also, there are a number of organizers of special sports events, ranging, for instance, from the organizers of the annual Rotterdam Marathon to the Olympic Games. These all provide material to broadcast and have TV rights to sell.

There is the Royal Dutch Football Association $(K \mathcal{N} V B)$. They organize the football competition in the Netherlands, both the professional and amateur leagues, and they represent the interests of football in general and among other things, the interests of professional football clubs in particular with regard to various matters.

There is the Association of Cable Companies in the Netherlands (VECAI). They have a representative role when it comes to protecting the interests of cable companies in the Netherlands. Apart from a few small companies who are still in the hands of local government, most cable companies enjoy membership.

There are a large number of sports associations in the Netherlands, which fulfil the same function as the KNVB. Those representing major sports in the Netherlands like tennis, speed skating and cycling mind their own 


\section{Government}

Various levels of government are actors in the network. affairs. The smaller sports associations mostly are represented by the Dutch sports federation NOC*NSF.

There is a Media Act, which falls under the responsibility of the Minister for Culture. The Media Act regulates both TV companies as well as cable companies.

Anti-trust matters and issues of fair competition fall under the Minister of Economic Affairs.

Besides, most municipalities might have sold off their cable companies, but they still largely determine in one way or the other which TV channels are passed through to the cable subscribers. The idea is that in this way the cable subscribers, who are also voting residents in a municipality, can have a say in what they receive and pay for.

Overseeing all this is the European Community. They too hold a watchful eye over anti-trust matters and issues of fair competition (for instance, because of an EC ruling Endemol had to sell its share in HMG).

\footnotetext{
${ }^{1}$ Source: http://www.vecai.nl/facts.htm

${ }^{2}$ At the end of May 1996, the Philips - KPN joint venture Teleselect was taken over by Nethold while Philips and KPN took an interest in the company. In early September 1996, Nethold and French Canal Plus announced a merger.
}

\section{REFERENGES}

Anderson, J. G., Håkansson, H. and Johanson, J. (1994). 'Dyadic business relationships within a business network context'. Fournal of Marketing, 58, 1-15.

Ariño, A. and de la Torre, J. (1998). 'Learning from failure: towards an evolutionary model of collaborative ventures'. Organization Science, 9, 3, 306-25.

Ariño, A. and Doz, Y. (2000). 'Rescuing troubled alliances . . before it's too late'. European Management Fournal, 18, 2, 173-82.

Ariño, A., de la Torre, J. and Ring, P. S. (2001). 'Relational quality: managing trust in corporate alliances'. California Management Review, 44, 1, 109-31.

Axelrod, R. (1990). The Evolution of Co-operation, 2nd edition. Harmondsworth: Penguin Books.

Axelsson, B. and Easton, G. (Eds) (1992). Industrial Networks: A New View of Reality. London: Routledge.

Bazerman, M. H. and Neale, M. A. (1992). Negotiating Rationally. New York: The Free Press.

De Bruin, H., Ten Heuvelhof, E. and Kuit, M. (1999). Sport7: Opkomst en ondergang van een Nederlandse sportzender. Rotterdam: Aristos.

Doz, Y. L. (1996). 'The evolution of cooperation in strategic alliances: initial conditions or learning processes?' Strategic Management Fournal, 17, 55-83.

Doz, Y. L., Olk, P. M. and Ring, P. S. (2000). 'Formation processes of R\&D consortia: which path to take? Where does it lead?' Strategic Management Fournal, 21, 239-66.

Fisher, R., Ury, W. and Patton, B. (1991). Getting to Yes: Negotiating Agreement Without Giving In, 2nd edition. Harmondsworth: Penguin Books. 
Giddens, A. (1979). Central Problems in Social Theory: Action, Structure and Contradiction in Social Analysis. Basingstoke: Macmillan.

Håkansson, H. and Johanson, J. (1992). 'A model of industrial networks'. In Axelsson, B. and Easton, G. (Eds), Industrial Networks: A New View of Reality. London: Routledge, 28-34.

Håkansson, H. and Johanson, J. (2001). 'Business network learning - basic considerations'. In Håkansson, H. and Johanson, J. (Eds), Business Network Learning. Amsterdam: Pergamon, 1-13.

Halinen, A., Salmi, A. and Havila, V. (1999). 'From dyadic change to changing business networks: an analytical framework'. Fournal of Management Studies, 36, 6, 779-94.

Lundgren, A. (1992). 'Coordination and mobilisation processes in industrial networks'. In Axelsson, B. and Easton, G. (Eds), Industrial Networks: A New View of Reality. London: Routledge, 144-65.

Mizruchi, M. S. and Galaskiewicz, J. (1993). 'Networks of inter-organizational relations'. Sociological Methods and Research, 22, 1, 46-70.

Oliver, C. (1991). 'Strategic responses to institutional processes'. Academy of Management Review, 16, $1,145-79$.

Pahlberg, C. (2001). 'Creation and diffusion of knowledge in subsidiary business networks'. In Håkansson, H. and Johanson, J. (Eds), Business Network Learning. Amsterdam: Pergamon, 169-81.

Pfeffer, J. and Salancik, G. R. (1978). The External Control of Organizations: A Resource Dependence Perspective. New York: Harper \& Row.

Porac, J. F., Thomas, H. and Baden-Fuller, C. (1989). 'Competitive groups as cognitive communities: the case of the scottish knitwear manufacturers'. Fournal of Management Studies, 26, 4, 397-416.

Powell, W. W. and DiMaggio, P. J. (Eds) (1991). The New Institutionalism in Organizational Analysis. Chicago, IL: University of Chicago Press.

Reger, R. K. and Huff, A. S. (1993). 'Strategic groups: a cognitive perspective'. Strategic Management fournal, 14, 103-24.

Ring, P. S. and Van de Ven, A. H. (1994). 'Developmental processes of cooperative interorganizational relationships'. Academy of Management Review, 19, 1, 90-118.

Silver, L. and Wedin, T. (2001). 'Collective innovation - the case of Scania-Cummins'. In Håkansson, H. and Johanson, J. (Eds), Business Network Learning. Amsterdam: Pergamon, 107-26.

Spender, J.-C. (1989). Industry Recipes. Oxford: Basil Blackwell.

Sztompka, P. (1991). Society in Action: The Theory of Social Becoming. Cambridge: Polity Press.

Uzzi, B. (1997). 'Social structure and competition in interfirm networks: the paradox of embeddedness'. Administrative Science Quarterly, 42, 35-67.

Van de Ven, A. H. and Scott Poole, M. (1995). 'Explaining development and change in organizations'. Academy of Management Review, 20, 3, 510-40.

Yin, R. K. (1989). Case Study Research: Design and Methods. Beverly Hills, CA: Sage.

Zajac, E. J. and Olsen, C. P. (1993). 'From transaction cost to transactional value analysis: implications for the study of interorganizational strategies'. Journal of Management Studies, 30, 1, 131-45. 